\title{
Development of Food Agriculture Based on Superiority Cultivation Area in Tanjung Api-Api, Banyuasin District
}

\author{
Syuhada A. Umar' ${ }^{*}$, M. Edi Armanto ${ }^{2}$, Ari Siswanto ${ }^{3}$, and Muhammad Yazid ${ }^{2}$ \\ ${ }^{1}$ Study Program of Environment Science, Sriwijaya University, South Sumatra, Indonesia \\ ${ }^{2}$ Faculty of Agriculture, Sriwijaya University, South Sumatra, Indonesia \\ ${ }^{3}$ Faculty of Engineering, Sriwijaya University, South Sumatra, Indonesia
}

\begin{abstract}
Leading commodity development area is a developed area for one or a combination of superior commodities that comply with the land use characteristics that provide the highest farm household's income, communities, and the region. This research was aimed to determine and describe the factors which have a significant effect on the superiority of Tanjung Api-Api (TAA) area, measure and analyze of the superiority of TAA cultivation area for food crops,and formulate a grand strategy matrix for food crops development based on its regional. The descriptive methods, Policy Analysis Matrix (PAM), and Grand Strategy Analysis. The factors which affect the superiority of TAA cultivation area include ecological, socio-cultural, and economic factors. The result shows, rice and corn plants included in the S1 category or suitable for cultivation in the TAA region with Soil Mapping Unit (SPT) value of $20.70 \%$. Socio-cultural aspects that affect the development of food agriculture such as the labors, Village Unit Cooperative (KUD), and Farmers Group that support agricultural development. Rice and corn crops have 0.69 and 0.97 on the competitive advantage (PCR) value respectively, therefore the rice and corn plants are concluded to have a competitive advantage. The comparative advantages (DRCR) value shows 0.68 and 0.65 for rice and corn plants respectively, which have comparative advantages and have the potential to develop in TAA area. Food crops in the TAA area are in a good competitive position. The strategy that must be applied under these conditions is to support an aggressive growth policy (Growth-oriented strategy).
\end{abstract}

Keyword: Regional Development, Food Agriculture, Superiority Area

\footnotetext{
*Corresponding author: Syuhadaadji@gmail.com
} 


\section{Introduction}

Banyuasin District located in South Sumatera Province, which has a strategic geographical location because it is located in the inter-provincial route. The area of Banyuasin District is $11,832.69 \mathrm{Km}^{2}$.Banyuasin District has 19 districts, Banyuasin II District as the largest district with an area of $3,632.4 \mathrm{Km}^{2}$ or about $30.70 \%$, and the smallest district is SumberMargaTelang District with an area of $174.89 \mathrm{Km}^{2}$ or around $1.48 \%$ of the Banyuasin District area. Natural resources in Banyuasin District are very abundant and have the potential to be developed [1].

The agricultural land potential would not have any significant effect on regional growth if it does not utilize optimally. The evaluation of the potential land resources in an area is an initial activity to create data or make information on land resources to determine the direction and policies of agricultural development [2].

The marginal land empowerment such as wetlands for agriculture is part of national development. The wetlands utilization as agricultural land should be managed with a sustainable farming system by emphasizing the wetland ecosystems sustainability [3]. One of the agricultural sub-sectors which has good potential to be developed and improved in wetlands is the sub-sector of food crops. Food crops are one of the good potential agricultural sub-sectors to be developed because they have higher economic value and added value compared to other commodities [4].

Moreover, food crop commodities also have a strategic role, especially in efforts to fulfill the availability of food and to improve the farmer's welfare and provided employment [5]. Food crop commodities also have higher sale value, diversity of commodity types, and adequate land availability. Food corps commodities consist of rice, corn, soybeans, peanuts, green beans, cassava, sweet potatoes, and sorghum [6].

The national food needs fulfillment requires an additional area of agricultural land so the government intensifies the use of marginal lands. The national needs to increase food production are trigger to empower the marginal land to be self-sufficient in rice [7]. Moreover, the rice industry always be special attention from the government in three types of government intervention such as fertilizer subsidies, price support and import or quota restrictions [8].

One of the internal factors that have a good impact on the development of the Banyuasin District was the development plan of Tanjung Api-Api port which symbolizes national water transportation. It also could be an encouragement of attraction for Banyuasin District and other strategic issues that would give effect for changes in spatial planning which require a strategy and new policy directions for planning, utilizing, and controlling the natural resources uses artificial resources and human resources. The development was carried out to promise sustainable economic growth, social justice, and ecological protection [9]. This research focused on the cultivation area. The area was determined by its main function to be cultivated on the basis of the conditions and potential of natural resources, human resources, and artificial resources [10].

Leading commodity development area is a developed area for one or combination of superior commodities that fulfill the land use characteristics, it provides the highest income for farm households, communities and the region itself without eliminating the function of natural resources and the environment as a supporter of the agricultural system in the region [11].

The objectives of this research were to describe and determine the factors which have a significant effect on the superiority of Tanjung Api-Api area, measure and analyze the superiority of Tanjung Api-Api cultivation area for food crops, as well as formulating strategies for developing food crops based on the excellence of the region. 


\section{Methodology}

This research was conducted in the Tanjung Api-Api area, which is located in Banyuasin District, South Sumatra Province, Indonesia. The location was chosen purposively with the consideration that the Tanjung Api-Api area is one of the main food storage and commodity-producing areas in Banyuasin District. The research was conducted for 8 months period from May 2019 to December 2019.

The data used were primary and secondary data. Primary data was collected from field observation and interview with related parties of this research such as farmers, businessmen, community, and government in the research area. Whereas the secondary data was obtained from formal institutions such as the sub-district office, Agriculture Office of Banyuasin District, Regional Development Planning Agency and Research and Development Agency of Banyuasin District, and Central Bureau of Statistics of Banyuasin District. Data was collected from a combination of several methods, such as structured interviews, in-depth interviews, and observations.

To determine the factors which affect the superiority of the Tanjung Api-Api region by using descriptive analysis based on in-depth interviews and questionnaire interviews. To determine superior food crops using the Policy Analysis Matrix (PAM) analysis method. PAM could be known by the ratio of comparative advantage (DRCR), competitive (PCR), and the impact of policies or it could be calculated thoroughly and systematically (the output was a private and social benefit, efficiency and the amount of government intervention incentives for the producers, the consumers, and the collectors). To develop a strategy for developing agricultural food crops in the TanjungApi-Api cultivation area, it was carried out through several stages of analysis including IFE (Internal Factors Evaluation) matrix analysis, EFE (External Factors Evaluation) matrix, IE (Internal External) Matrix, SWOT Analysis, and analysis Grand Strategy.

\section{Result and Discussion}

\subsection{Affecting factors the superiority of Tanjung Api-Api area}

The first objective was to describe and analyze the factors that affected the development of food crops in Tanjung Api-Api area, Banyuasin District was carried out by descriptive analysis and interviews with respondents. There were three main factors that influence the ecological, socio-cultural, and economic factors with the following explanation:

\subsubsection{Ecological Factor}

Ecological factors were the main aspects that be the main focus in developing the region. The success of farming was largely determined by the land suitability aspect in the research location. Crop yields were mainly determined by ecological factors including climate, soil and pests, and diseases. The ecological factors that affect food crop development in the Tanjung Api-Api region were land suitability aspects [12].

Plants will grow well when soil fertility and other environmental factors could support their growth. The most important environmental factors of rice and corn were climate, physical condition, and soil fertility. Based on these factors were classified into 4 land capability classes, namely S1 (very suitable), S2 (Suitable), S3 (marginal appropriate), N1 (Temporary unsuitable), N2 (Permanently unsuitable) [13].

Based on the criteria of soil quality and land use requirements comparison, and the Soil Mapping Unit (SPT) of rice and corn, the land suitability for rice and corn in the research 
area was classified as a very appropriate classification (S1), appropriate class ( S2), and marginally suitable (S3) was found in almost all research areas, temporary classes were not suitable (N1) and permanent unsuitable (N2) were found along the waters of the Sungsang River. The land suitability in the research area could be seen in Table $\mathbf{1 .}$

Table 1. Land Suitability in Research Areas

\begin{tabular}{|c|c|c|c|c|c|c|c|}
\hline \multirow{2}{*}{ SPT } & \multirow{2}{*}{$\begin{array}{c}\text { Land } \\
\text { suitability } \\
\text { class }\end{array}$} & \multicolumn{2}{|c|}{2000} & \multicolumn{2}{|c|}{2012} & \multicolumn{2}{|c|}{2018} \\
\hline & & $\mathrm{Ha}$ & $\%$ & $\mathrm{Ha}$ & $\%$ & $\mathrm{Ha}$ & $\%$ \\
\hline 1 & S1 & 26,489 & 37.20 & 16,247 & 22.81 & 14,740 & 20.70 \\
\hline 2 & S2 & 32,503 & 45.64 & 41,791 & 58.68 & 42,325 & 59.43 \\
\hline 3 & S3 & 9,938 & 13.95 & 8,568 & 12.03 & 8,651 & 12.15 \\
\hline 4 & N1 & 847 & 1.19 & 1,984 & 2.79 & 2,353 & 3.30 \\
\hline 5 & $\mathrm{~N} 2$ & 1,438 & 2.02 & 2,625 & 3.69 & 3,146 & 4.42 \\
\hline & Total & 71,215 & 100.00 & 71,215 & 100.00 & 71,215 & 100.00 \\
\hline
\end{tabular}

Source: Thematic maps, landsat imaginary analyses (2018)

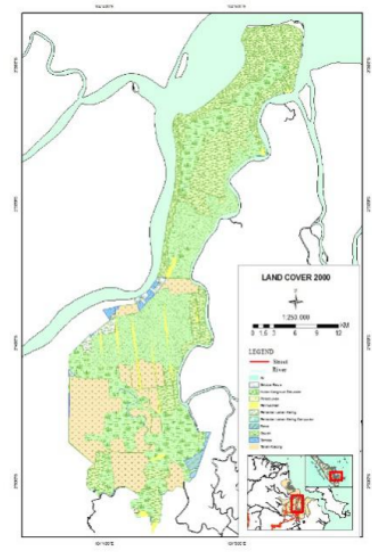

2000

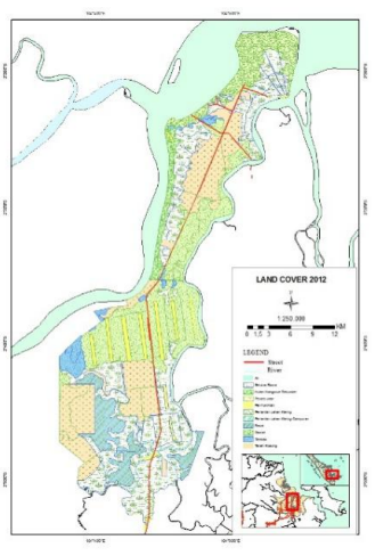

2012

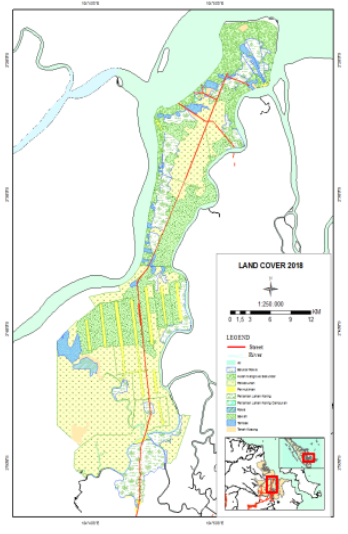

2018

Fig. 1. Land Cover in TAA Region, Banyuasin

\subsubsection{Socio-Cultural Factor}

A. Labors

The fields area was planted on 2 Ha with labor costs incurred by farmers for rice and corn crops around 90,000 IDR/day. Daily wages were given to labor was clean. It means exclude food and other necessities. Other wages were around 75,000 IDR to 80,000 IDR/day, it could be a net wages and lunch, usually, if the wages were like that the owner's farmer would bear lunch or snacks for the workforce. Workers who were paid were usually from outside family. Compared to agriculture development in the last period, the wages were higher. Nowadays, wages could increase by more than $50 \%$. 
Table 2. The difference use of labor before and after development

\begin{tabular}{|c|c|c|c|}
\hline $\mathrm{Nr}$ & Description & $\begin{array}{c}\text { HOK } \\
\text { (Rp/HOK/MT) }\end{array}$ & Difference \\
\hline 1 & HOK Rice 2000 & 297,335 & \multirow{2}{*}{508,033} \\
\hline 2 & HOK Rice 2018 & 805,368 & \\
\hline 3 & HOK Corn 2000 & 268,236 & \multirow{2}{*}{$1,082,728$} \\
\hline 4 & HOK Corn 2018 & $1,350,964$ & \\
\hline
\end{tabular}

Source: Data analysis, 2018

It could be seen from the above calculation, that the labor needs were higher in 2018 than in 2000, it means that the expenditure of farmer costs variable was more spent in 2018 due to wages keep up with the times and the increase of the minimum wage (UMR). In addition, the labor needed was relatively a lot because land ownership tends to increase. It could be seen in Table 2. there was a difference of around 508,033 IDR in the HOK of rice and around 1,082,728 IDR in the HOK of corn.

Another reason was to comply rice self-sufficiency and the use of good seeds so the crop failure was rare happened, for corn plants, the wages were relatively higher because it was influenced by better infrastructure, shipments distribution out of Banyuasin area was higher so that the corn crop harvest was relatively driven to produce even more.

B. Village Unit Cooperative (KUD)

Data on village unit cooperatives (KUD) in the TanjungApi-Api cultivation area, Banyuasin District, could be seen in Table 3 below:

Table 3.Difference of KUD before and after development

\begin{tabular}{|c|l|c|c|}
\hline $\mathrm{Nr}$ & Description & Score & Note \\
\hline 1 & KUD* & 2 & A \\
\hline 2 & KUD** & 2 & DA \\
\hline 3 & Significance & 0.776 & Accepted $\mathrm{H}_{0}$ \\
\hline
\end{tabular}

Note: KUD* : Before Development KUD** : After Development
A : Agree
DA : Disagree

Based on the results, it was obtained a score of 2 and has no significant value $(>0.05)$, it means that Ho was accepted and Ha was rejected. The results show that the community relatively said that their village unit cooperatives did not work well even the worst was not functioning the same once.

\section{Farmers Group}

One of the activities was carried out at the research location to observe farmers' group development comparisons before and after the development plan that had been carried out by the government. For further information, it could be seen from Table 4.

Table 4. Difference of Gapoktan Before and After Development

\begin{tabular}{|c|c|c|c|}
\hline $\mathrm{Nr}$ & Description & Score & Note \\
\hline 1 & Gapoktan* & 2 & DA \\
\hline 2 & Gapoktan** & 4 & A \\
\hline 3 & Significance & 0.000 & Reject $\mathrm{H}_{0}$ \\
\hline
\end{tabular}


In 2000, there was no development yet many people said that it was not good.It was proven by number 2 (two) which was the average response of the community, it means that farmer groups did not play an active role in agricultural activities. At that time, the existing farmer groups were not as active as now.

However, it could be seen in the community's perception that most of them expressed their agreement with the development in the research area due to its could increase the productivity and the progress of farmer groups. Evidenced by the average score obtained was number 4 which means has a significant impact (Sig $2(<0.05)$ ) between the impact of Top-Down development with farmer group in the research area.

\subsubsection{Economic Factor}

Household farming was carried out in order to measure the impact of development that has been done by the government on the farmer's welfare. The analysis was carried out using statistical analysis by different tests. Comparing the differences between before and after the development by the government. It could be explained on Table $\mathbf{5}$.

Table 5. Characteristics of rice farmer house holding farming (2000\&2018)

\begin{tabular}{|c|c|r|r|}
\hline $\mathrm{Nr}$ & Farm parameters & \multicolumn{1}{|c|}{2000} & \multicolumn{1}{|c|}{2018} \\
\hline 1 & Variable costs (Rp) & $2,805,046$ & $13,472,490$ \\
\hline 2 & Depreciation fee (Rp) & 176,334 & 420,501 \\
\hline 3 & Total cost of production $(\mathrm{Rp})$ & $2,981,380$ & $13,892,992$ \\
\hline 4 & Selling price $(\mathrm{Rp})$ & 1,263 & 4,262 \\
\hline 5 & Production $(\mathrm{Kg})$ & 8,408 & 10,772 \\
\hline 6 & Total revenue (Rp) & $10,210,616$ & $45,912,075$ \\
\hline 7 & Total income (Rp) & $7,229,326$ & $32,019,084$ \\
\hline 8 & RC Ratio & 2 & 3 \\
\hline
\end{tabular}

Source: Farm analysis and different test

The increase in rice farmers' household income gave around $50 \%$, it could be confirmed from the $\mathrm{RC}$ ratio $(>1)$ that has been calculated that the farmers did not have losses. It could be said that farmers have a profit if the selling price was around 1,263 IDR in 2000, and around 4,262 IDR in 2018, but if the selling price was decreasing, the RC ratio would be $<1$. The results of statistical analysis by the different methods have $\operatorname{Sig}<0.005$, it means Ho was rejected and Ha was accepted. It means that there was a significant difference in the household income of rice farmers between before and after the development. The increase occurred due to government assistance in terms of infrastructure development both inland infrastructures such as roads and the port of TanjungApi-Api. 
Table 6.Characteristics of corn farmer house holding farming (2000\&2018)

\begin{tabular}{|c|c|c|c|}
\hline $\mathrm{Nr}$ & Farm parameters & 2000 & 2018 \\
\hline 1 & Variable costs $(\mathrm{Rp})$ & $3,421,325$ & $11,688,620$ \\
\hline 2 & Depreciation fee $(\mathrm{Rp})$ & 176,334 & 424,168 \\
\hline 3 & Total cost of production $(\mathrm{Rp})$ & $3,597,659$ & $12,112,788$ \\
\hline 4 & Selling price $(\mathrm{Rp})$ & 1,336 & 3,323 \\
\hline 5 & Production $(\mathrm{Kg})$ & 8,447 & 14,569 \\
\hline 6 & Total revenue $(\mathrm{Rp})$ & $11,280,434$ & $48,413,452$ \\
\hline 7 & Total income $(\mathrm{Rp})$ & $7,682,775$ & $36,300,663$ \\
\hline 8 & RC Ratio & 2 & 3 \\
\hline
\end{tabular}

Source: Farm analysis and different test

The data of corn farmer household income could be seen that an increase in production up to $35 \%$ with an increase of more than $30 \%$ in the total cost of production. However, after farming analysis, corn farmer income could cover the entire total cost of production. That data was confirmed by an increase in the RC ratio of corn farmer household income $(>1)$ in 2000 and RC radio increased to a value of 3 in 2018. The results of the statistical analysis of the different test methods $(\mathrm{a}=0.005)$ have a significant impact $(\mathrm{Sig}<0.005)$, where Ho was rejected and Ha was accepted, which means the construction of Top-Down has a significant impact on the income of corn farmers.

\subsection{PAM Analysis}

The table shows PCR and DRCR value from corn farming. PCR (Private Cost Ratio) is the ratio of domestic costs to value-added in private prices. The PCR value shows financial efficiency. The PCR value illustrates how many corn farming production systems could be produced to pay for all the domestic factors they use and remain competitive. PCR value gave 0.69 for rice and 0.97 for corn, it means that the production system of rice and corn farming was able to finance its domestic factors at private prices.

Based on the PCR value, rice and corn commodities have a competitive advantage, because to produce one unit of value-added at private prices has only required less than one unit of domestic input. In other words, specifically in the research area has the ability to economically finance and produce rice and corn efficiently, and financially the rice and corn produced could compete in the domestic and international markets. However, the maximum benefit could be obtained if the rice and corn production system were able to minimize the PCR value, by minimizing the cost of domestic factors or maximizing added value [14].

Table7. The Result Private Cost Ratio and Domestic Resource Cost Ratio Rice and Corn farming

\begin{tabular}{|c|c|c|c|}
\hline \multirow{2}{*}{$\mathrm{Nr}$} & \multirow{2}{*}{ Farming } & Private & Domestic Resource \\
\cline { 3 - 4 } & & Cost Ratio (PCR) & Cost Ratio (DRCR) \\
\hline 1 & Rice & 0.69 & 0.68 \\
\hline 2 & Corn & 0.97 & 0.65 \\
\hline
\end{tabular}

DRCR value of corn farm gave 0.65 , indicates that its farm has a comparative advantage. This value means that to produce corn in the Banyuasin District, TanjungApiApi cultivation area requires the domestic resource cost at least $65 \%$ of import cost required. In other words, every $\$ 1.00$ needed to import these products, only requires a domestic cost of $\$ 0.65$, it means that to fulfill the domestic needs, the corn commodity 
should be processed and have its own production plant in TanjungApi-Api cultivation area, Banyuasin District and did not need importing. Data from the field could be confirmed that the Banyuasin District, especially in the research area, has not imported corn commodity [15].

Likewise, rice farming has a DRCR value of 0.68 , meaning that to produce rice in the TanjungApi-Api cultivation area, Banyuasin District only requires a domestic resource cost of $68 \%$ or it was sufficient to save foreign exchange if it still maintains the Banyuasin District as the largest food granary so that the rice commodity also has comparative advantages. Thus the commodity of rice and corn both have a comparative advantage. The concept of comparative advantage was a measure of potential competitiveness in terms of the competitiveness that would be achieved in the economy experiencing no distortion at all [16]. The aspects related to the concept of comparative advantage are economic viability and those related to competitive advantage and the financial viability of an activity.

\subsection{Regional Excellence-based Food Agriculture Development Strategy}

The strategy of food crops development in the TanjungApi-Api cultivation area, Banyuasin District, based on regional superiority was carried out through several stages of analysis including IFE (Internal Factors Evaluation) matrix analysis, EFE (External Factors Evaluation) matrix analysis, IE (Internal External) matrix analysis, and Grand Strategy analysis.

\subsubsection{Internal Factors Evaluation (IFE) Matrix Analysis}

Based on the results of a paired comparison analysis on aspects of strengths and weaknesses in the development of food agriculture in the TanjungApi-Api Area, the following results were obtained:

Table 8. IFE matrix for food agriculture development in the TAA area

\begin{tabular}{|c|c|c|c|c|}
\hline Nr. & Strength & Weight & Rating & Score \\
\hline 1 & Land suitability is very suitable in TAA area & 0.10 & 4 & 0.42 \\
\hline 2 & Availability of production input & 0.12 & 3 & 0.37 \\
\hline 3 & Commodity is a staple food crop in community & 0.02 & 4 & 0.09 \\
\hline 4 & Gapoktan is active and support agricultural activities & 0.11 & 3 & 0.34 \\
\hline 5 & $\begin{array}{c}\text { Agricultural technology are modern ex. tractor, } \\
\text { combine harvester. }\end{array}$ & 0.15 & 3 & 0.45 \\
\hline & $\begin{array}{c}\text { Sub Total } \\
\text { Weakness }\end{array}$ & 0.51 & & 1.65 \\
\hline 1 & $\begin{array}{c}\text { Level innovation and creativity farming community is } \\
\text { still low }\end{array}$ & 0.10 & 1 & 0.10 \\
\hline 2 & $\begin{array}{c}\text { Physical infrastructure, water management and roads } \\
\text { production are inadequate }\end{array}$ & 0.11 & 2 & 0.22 \\
\hline 3 & Weak institutional of KUD \\
\hline 4 & $\begin{array}{c}\text { The low level of community participant towards new } \\
\text { program }\end{array}$ & 0.16 & 2 & 0.32 \\
\hline 5 & $\begin{array}{c}\text { The unavailability of information access to modern } \\
\text { market }\end{array}$ & 0.06 & 2 & 0.20 \\
\hline & $\begin{array}{c}\text { Sub Total } \\
\text { Total }\end{array}$ & 0.49 & & 0.11 \\
\hline & \begin{tabular}{c} 
(1.00 \\
\hline
\end{tabular} & & 2.60 \\
\hline
\end{tabular}

Based on Table 8. on the strength factor, the highest yield with a weight of 0.15 with a rating of 3 and a score of 0.45 was the use of fairly modern technology. Farmers in 
Banyuasin District were currently utilizing various agricultural technologies such as tractors, for harvesting using combine harvester which was partly aids from the central government. The technology also used by farming communities was the RMU (Rice Milling Unit) for post-harvest activities or grinding rice or grain into rice in Banyuasin District.

While the weakness factor was the weakness of the KUD institution which has a weight of 0.16 with a rating of 2 and a score of 0.32 to be one of the obstacles in the development of food agriculture in the TanjungApi-Api region. KUD Institutions should have an important role in regulating the management of agricultural activities, KUD also plays a role as one of the village-level financial institutions or farmers who provide assistance in the form of capital or inputs for agricultural activities so as not to be constrained by capital and other problems.

The total score obtained from the IFE matrix was 2.60, which indicates that food agriculture development activities in the TanjungApi-Api region were in an Internal position that was strong enough to minimize aspects of weakness with the strengths contained in the region.

\subsubsection{External Factors Evaluation(EFE) Matrix Analysis}

Based on the paired comparison analysis result on strengths and weaknesses aspects in food agriculture development in the TanjungApi-Api Area, the following results were obtained:

Table 9. EFE matrix for food agriculture development in the TAA area

\begin{tabular}{|c|l|c|c|c|}
\hline Nr. & Opportunity & Weight & Rating & Score \\
\hline 1 & $\begin{array}{l}\text { Food agriculture development to support food self- } \\
\text { sufficiency }\end{array}$ & 0.03 & 4 & 0.12 \\
\hline 2 & Agriculture instructor done intensively & 0.01 & 4 & 0.04 \\
\hline 3 & Rice export demand from Banyuasin district still hight & 0.13 & 3 & 0.39 \\
\hline 4 & $\begin{array}{l}\text { Agricultural equipment and machinery assistance from } \\
\text { government }\end{array}$ & 0.08 & 4 & 0.32 \\
\hline 5 & $\begin{array}{l}\text { Give important contribution to farmer's household } \\
\text { economy }\end{array}$ & 0.25 & 4 & 1.00 \\
\hline & Sub Total & 0.50 & & 1.87 \\
\hline & Threat & & & \\
\hline 1 & $\begin{array}{l}\text { Low interest of young generation to work in } \\
\text { Agricultural sectors }\end{array}$ & 0.06 & 1 & 0.06 \\
\hline 2 & Land conversion occurs & 0.03 & 2 & 0.06 \\
\hline 3 & Land fragmentation occurs & 0.03 & 3 & 0.09 \\
\hline 4 & Price is controlled by Tengkulak & 0.20 & 2 & 0.40 \\
\hline 5 & Regional leakage occurrence & 0.18 & 3 & 0.54 \\
\hline & Sub Total & 0.50 & & 1.15 \\
\hline & $\quad$ & & 3.02 \\
\hline
\end{tabular}

Based on Table 9. the strength factor has a 0.15 with a rating of 3 and a score of 0.45 was the use of fairly modern technology. Farmers in Banyuasin District were currently utilizing various agricultural technologies such as tractors, for harvesting using combine harvester, Rice Milling Unit (RMU) for post-harvest activities, or grinding rice or grain into the rice which was partly aids from the central government.

While the weakness factor was the weakness of the Village Unit Cooperative institution which has 0.16 with a rating of 2 and a score of 0.32 to be one of the obstacles in food agriculture development. Village Unit Cooperative (KUD) institutions should have an important role in regulating the management of agricultural activities, Village Unit 
Cooperative (KUD) also plays a role as one of the village-level financial institutions or farmers who provide assistance in the form of capital or inputs for agricultural activities so as not to be constrained by capital and other problems.

The total score obtained from the IFE matrix was 2.60, which indicates that food agriculture development activities in the TanjungApi-Api region were in an Internal position that was strong enough to minimize aspects of weakness with the strengths contained in the region.

\subsubsection{Internal-External(IE) Matrix Analysis}

The aim of IE matrix analysis was to determine the strategic position and appropriate strategic alternatives of the food agriculture development in the TanjungApi-Api region. The results of IFE and EFE matrices were used to compile the IE matrix, so it could know the position of the agricultural development plan in the TanjungApi-Api region and the right strategy to realize it. IE matrix analysis could be seen in Table $\mathbf{1 0 .}$

Table 10. IE matrix for food agriculture development in the TAA area

\begin{tabular}{|c|c|c|}
\hline Nr. & Matrix & Total Score \\
\hline 1 & Matrix IFE & 2.60 \\
\hline 2 & Matrix EFE & 3.02 \\
\hline
\end{tabular}

The average score on the IFE matrix gave 2.60 while the score on the EFE matrix gave 3.02. This shows the position of the food agriculture development in the Tanjung Api-Api region was on quadrant II, which was "growing and building" the position allows that the food crop agriculture development was to carry out intensive and integrative strategies.

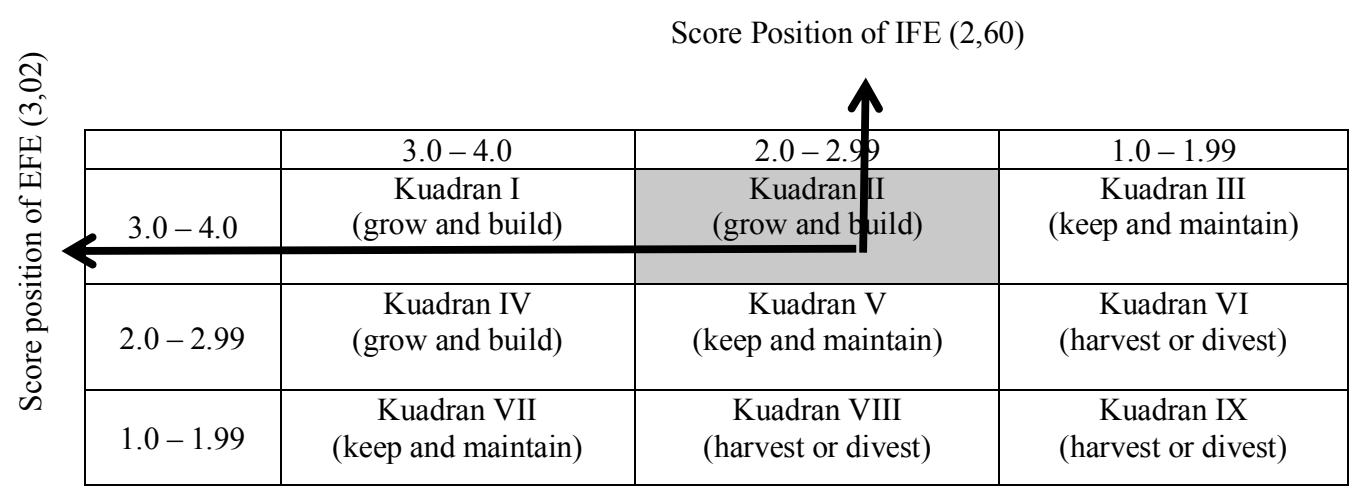

Fig 2. Position of food agriculture development in Matrix IE

An intensive strategy that could be carried out as one of the steps in develops food crops plan in the TanjungApi-Api region was by activating IP 200 and IP 300 cropping systems for rice and corn. In addition to reactivating agricultural institutions such as Village Unit Cooperatives (KUD) that work together with Indonesia National Logistical Supply Organization to accommodate agricultural products so the prices did not control by middlemen. The opportunities for food crop development in the TanjungApi-Api region such as rice export demand were still high from outside the region, which could support and encourage the development of food crop agriculture in Banyuasin District. Moreover, the 
strategic plan in making Banyuasin District as a food barn of South Sumatra Province was triggering the production facilities and agricultural machine tools assistance to develop infrastructure in agriculture.

\subsubsection{Grand Strategy Analysis}

The grand strategy matrix was also one of the tools used to formulate the strategy formula. Where food crop development plans in the TanjungApi-Api Region could be positioned into four quadrants based on their competitive ability.

\begin{tabular}{|c|c|c|c|}
\hline \multicolumn{3}{|c|}{ Rapid market growth } \\
\hline $\begin{array}{c}\text { Weak competitive } \\
\text { position }\end{array}$ & Kuadran II & Kuadran I & $\begin{array}{c}\text { Strong competitive } \\
\text { position }\end{array}$ \\
\cline { 2 - 3 } & Kuadran III & Kuadran IV & \\
\hline \multicolumn{2}{|c|}{ Slow market growth } \\
\hline
\end{tabular}

Fig 3. Position of food agricultural development in Matrix Grand Strategy

Grand Strategy Matrix Analysis was used to find out the plan for developing food crops in the TanjungApi-Api region which was in the quadrant where the development of food crops in the TanjungApi-Api region has a score of 2.52 which indicates that the competitive position was good, and has a strong competitive position.

Based on Figure 3. ,the food crop development in the TanjungApi-Api Region was in quadrant II, means that the plan was in a good situation because it has opportunities and strengths. The strategy that must be applied under these conditions was to support an aggressive growth policy (Growth-oriented strategy). The strategy that must be applied was market development, market penetration, product development, forward integration, backward integration, and horizontal integration.

\section{Conclusion}

Based on the results and discussion of superior agriculture development based food cultivation areas in Tanjung Api-Api Banyuasin District, the following conclusions could be formulated: Factors that affected the development of food crops based on regional superiority in TanjungApi-Api were ecological factors include land suitability, sociocultural factors labor aspects include labors, village unit cooperatives, and farmer groups, and also economic factors that include rice and corn farming in the Tanjung Api-Api Region.

PAM, PCR, and DRCR analysis were obtained PCR values of 0.69 for rice and 0.97 for corn, it could be concluded that the commodity of rice and corn has a competitive advantage. DRCR values obtained 0.68 for rice and 0.65 for corn, which shows that both of these farms have comparative advantages, which means they were very potential to develop in the Tanjung Api-Api area.

Analysis of the Grand Strategy Matrix shows that the food crop agriculture development in the Tanjung Api-Api region was in a good competitive position and has a strong competitive position. The strategy that must be applied under these conditions was to support an aggressive growth policy (Growth-oriented strategy). 


\section{References}

1. Badan Pusat Statistik (BPS). Banyuasin in Figures. Katalog BPS accessed from http://www.bps.go.id/. (2016)

2. E. Wildayana, M.Y. Hasan, M.E. Armanto, I. Zahri, D. Adriani, R.F. Sari, Nursittah, F. Lestari, and R. Oktavia. Jurnal Ekonomi Pembangunan 19, 1 (2018)

3. Sjarkowi, A. Arbain, M.E. Armanto, U. Santoso, J. Arjuna, Rifardi, A. Setiawan, J. Syahrul, Khairijon and Azizah. Environmental Quality of Sumatra 2007. PPLH Regional Sumatra, State Ministry for Environment, Pekanbaru, Riau (2007)

4. M.E. Armanto. Journal of Ecological Engineering 20, 5 (2019)

5. M.A. Adzemi, M.E. Armanto and E. Wildayana. BRIS Soil Improvement for Sustainable Crop Production. LAP LAMBERT Academic Publishing (2017)

6. M.S. Imanudin, M.E. Armanto and Bakri. Irrigation and Drainage 68, 3 (2019)

7. Wildayana and M.E. Armanto. Jurnal Ekonomi dan Studi Pembangunan (JESP) 9, 2 (2017)

8. M. Yazid, M.N. Shamsudin, K.A. Rahim, A. Radam and A. Muda. Journal Pertanika: Social \& Humanities 23 (2015)

9. M.N. Shamsudin, N.N. Ramli., A. Radam, and Z. Mohamed. Journal Pertanika: Social \& Humanities 23 (2015)

10. M.E. Armanto. Information System for Land Resources. Sriwijaya University Press. ISBN: 978-979-587-822-3. 272 pages. (2020)

11. Setiyanto. Research forum of Agro Ekonomi 31, 2 (2013)

12. J.O. Adejuwon. Food Crop Production in Nigeria. I. Present Effects of Climate Variability. Climate Research, Vol. 30: 53-60 (2005)

13. M.E. Armanto, M.A. Adzemi, E. Wildayana and M.S. Imanudin. Journal of Sustainability Science and Management 8, 1 (2013)

14. R.R. Nirmala and E.B. Santoso. Journal of Teknik Pomits 2, 2 (2013)

15. M. Keratorop, Widiatmaka, and Suwardi. Journal Plano Madani 5, 2 (2016)

16. Saptana, Sunarsih, and K.S. Journal Agroekonomi 24, 1 (2006) 